Eduvest - Journal of Universal Studies

Volume 1 Number 11, November 2021

p- ISSN 2775-3735 e-ISSN 2775-3727

\title{
SPATIAL ANALYSIS OF LAND USE CHANGES TOWARDS BANJARBARU CITY'S REGIONAL SPATIAL PLAN
}

\author{
Setya Etika Mulyasari, Suyanto, Gusti M. Hatta, Bambang Joko Priatmadi \\ Lambung Mangkurat University, Indonesia \\ E-mail: setya_etika89@yahoo.co.id, suyantomp1@gmail.com, \\ gustihatta52@gmail.com,bj_priatmadi@ulm.ac.id
}

\begin{tabular}{|c|c|}
\hline ARTICLE INFO & ABSTRACT \\
\hline $\begin{array}{l}\text { Received: } \\
\text { October, 26 } \\
2021 \\
\text { Revised: } \\
\text { November, } 16^{\text {th }} \\
2021 \\
\text { Approved: } \\
\text { November, } 18^{\text {th }} \\
2021\end{array}$ & $\begin{array}{l}\text { Banjarbaru City is one of the cities in South Kalimantan } \\
\text { Province which is developing quite rapidly from year to } \\
\text { year. Hence, it is necessary to research and study changes } \\
\text { in land use and their suitability with the city development } \\
\text { plan. The purpose of this study is to examine changes in } \\
\text { the area and types of land use changes in Banjarbaru City } \\
\text { within a period of } 8 \text { years, from } 2013 \text { to 2021, determine } \\
\text { the rate of land use change, and assess the suitability of } \\
\text { land use changes to the applicable Banjarbaru City spatial } \\
\text { plan. This research method is an overlay to see changes in } \\
\text { land use and the suitability of changes in land use with the } \\
\text { direction of spatial functions in the Regional Spatial Plan. } \\
\text { The result of this research is that in an area of } 16,414.00 \\
\text { ha (53.7\%) there is a change in land use in Banjarbaru City } \\
\text { in the period 2013-2021. The biggest land use changes are } \\
\text { dry land agriculture, vacant land, wetland agriculture, } \\
\text { housing, and villages. The use of dry land and agricultural } \\
\text { land has the largest decrease in area, which is } 15,090.71 \\
\text { ha or a decrease of } 365.5 \% \text {. The use of vacant land } \\
\text { increased in an area of } 14,715.684 \text { hectares or an increase } \\
\text { of almost } 4 \text { times. Wetland agriculture has decreased in } \\
\text { an area which is reduced by } 986.55 \text { ha or decreased by } \\
65.8 \% \text {. The use of land for housing/residential in the form } \\
\text { of housing or villages has also undergone considerable }\end{array}$ \\
\hline
\end{tabular}

Setya Etika Mulyasari, Suyanto, Gusti M. Hatta, Bambang Joko

Priatmadi. (2021). Spatial Analysis of Land Use Changes Towards

Banjarbaru City's Regional Spatial Plan. Journal Eduvest. 1(11):

1258-1267

How to cite:

E-ISSN:

Published by: $\quad$ https://greenpublisher.id/ 


changes. The use of residential land has increased by
528.105 hectares (44.626\%) and the village area to 444.32
ha (21.2\%). The suitability of land use with the RTRW in
Banjarbaru City is 16,742.86 ha (54.8\%) categorized as
appropriate, while an area of $13,779.69$ ha (45.2\%) is
categorized as not in accordance with the applicable
RTRW.

\section{INTRODUCTION}

Changes in land use are basically unavoidable in the implementation of development. Rapid population growth and the increasing demands of the community's needs for land will result in a conflict of interest over land use and a mismatch between land use and its designation plan (Yaping \& Min, 2009). It is necessary to discover the use of land in an area. It is intended to find out the impact of changes in land use on the carrying capacity of the land so that it has an impact on the decline in the quality of an environment. According to (Wuryanta, Susanti, Yani, \& Pabelan, 2015), the degradation or decline in environmental quality is related to land use patterns that do not pay attention to spatial planning rules, which will indirectly affect the level of pollution in the area. Changes in land use that do not pay attention to spatial and environmental aspects will have serious impacts on the environment. One of the impacts is the occurrence of natural disasters such as floods (Sivakumar, 2005). In determining the suitability of land use to the Regional Spatial Plan (RTRW) in Banjarbaru City supported by the development of existing remote sensing technology, there is no relevant study/information. Therefore, the researchers are interested in studying changes in land use during the period 2013-2021 and their suitability to the Banjarbaru City Spatial Plan that applies to the Geographic Information System (GIS) approach. This study aims to assess changes in the area and types of land use changes in Banjarbaru City within a period of 8 years, from 2013 to 2021 as well as to assess the suitability of land use changes to Banjarbaru City spatial planning in 2014-2034.

Based on the research objectives above, the results of this study are expected to be useful for Local Government of Banjarbaru City and decision makers in determining land use policies in Banjarbaru City. The Banjarbaru City Government in aligning land use with spatial planning and also for academics as additional material and reference material for further research.

\section{RESEARCH METHOD}

The research location was in Banjarbaru City, South Kalimantan Province. The research was carried out for 8 months. The tools used in this research are a set of computers with arcGIS 10.4 software for spatial analysis, GPS (Global Positioning System), and the Avenza Maps application for ground checking. The materials used in this study include the Banjarbaru City base map, the latest satellite imagery, the administrative boundary map, the 2014-2034 Banjarbaru City Spatial Plan Map.

This research was conducted using spatial analysis/map data by overlaying to see 
changes in land use and suitability of land use changes with the direction of spatial functions in the Regional Spatial Plan. In the implementation of this research, several stages were carried out. The stages are preparation, data collection, data processing, and data analysis.

\section{RESULT AND DISCUSSION}

\section{A. Changes in Land Use (2013-2021 Period)}

Land is a source of life and life for humans. Land has a very strategic function, both as a natural resource and as a space for development (Maclean, Robinson, \& Natcher, 2015). With an increasing development in all fields, be it agriculture, settlement, industry, the need for land is also increasing. With the increasing demand for land, the problems that arise are also increasing. This is because the availability of land is relatively fixed while the need for land continues to increase along with population growth and development activities (Bruinsma, 2009).

Taking into account that the need for land continues to increase while its availability is increasingly decreasing, the application of mechanisms for regulating land use and utilization to ensure that development and human life will be maintained in its sustainability needs to be continuously pursued and improved in quality. Land use is very dynamic from time to time, in the course of time there will be many changes (Lambin, Rounsevell, \& Geist, 2000). According to (Arsyad, 2006), land use change is essentially a development activity on the land. Land use change has a big potential impact on the biophysical and socioeconomic environment.

Land use data used as a comparison in analyzing land use changes are land use data in 2013 and the latest land use data (2021).

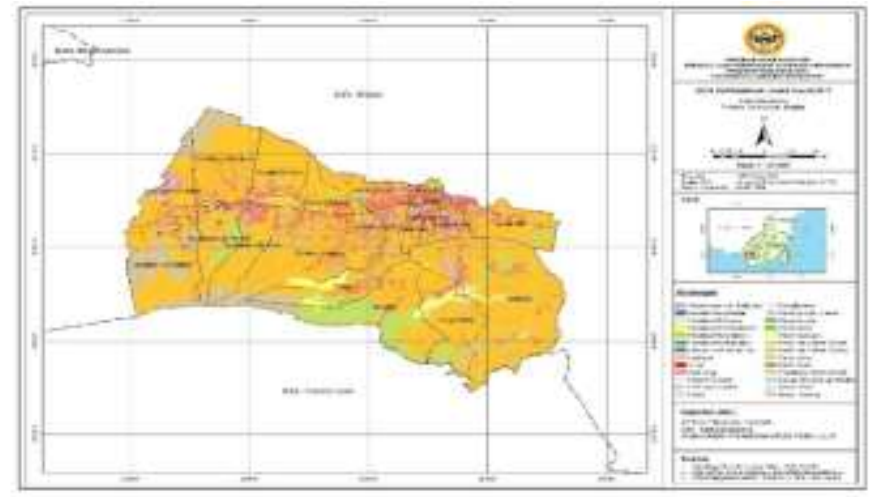

Figure 1 Land Use Map 2013

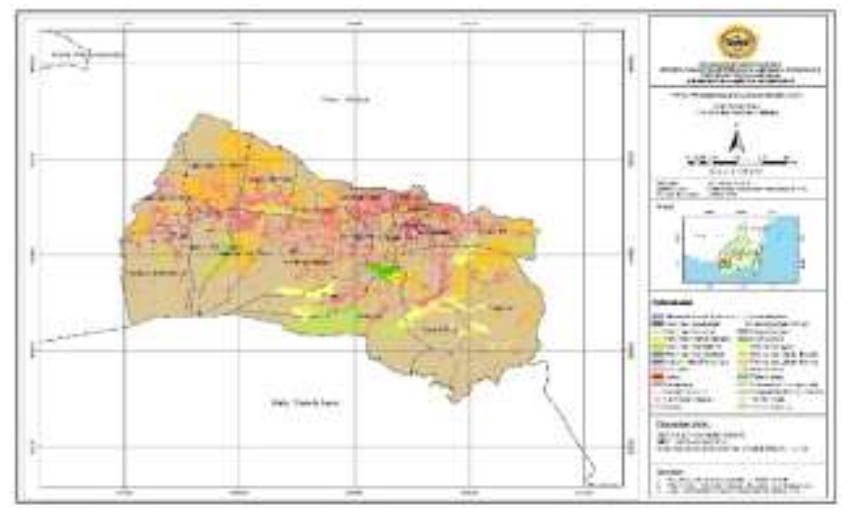

Figure 2 Land Use Map 2021 


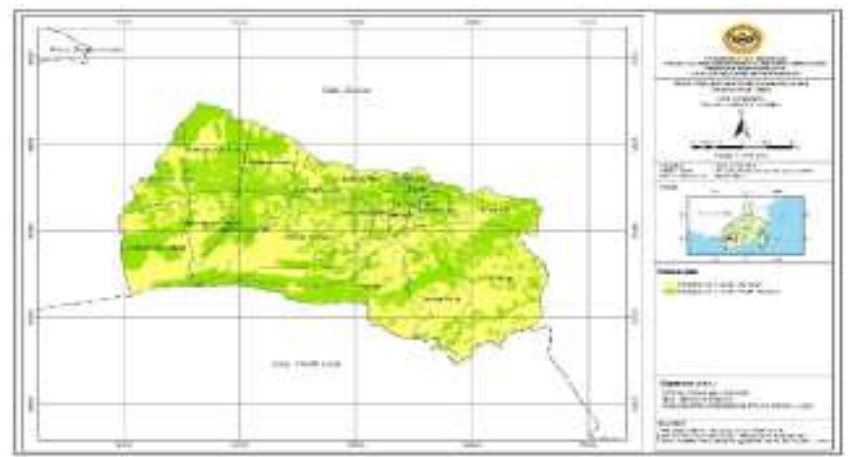

Figure 3 Map of Land Use Change for 2013-2021

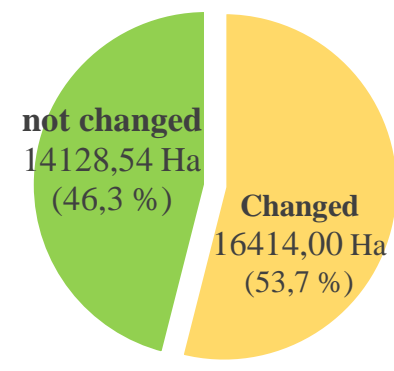

Figure 4. Graph of Land Use Change in Banjarbaru City Period 2013 - 2021

From the results of spatial analysis, it can be concluded that an area of 16,414.00 ha or an area of $53.7 \%$ of the total area of Banjarbaru City experienced changes in land use in the period 2013-2021, while the remaining area of $14,128.54$ ha or $46.3 \%$ did not change.

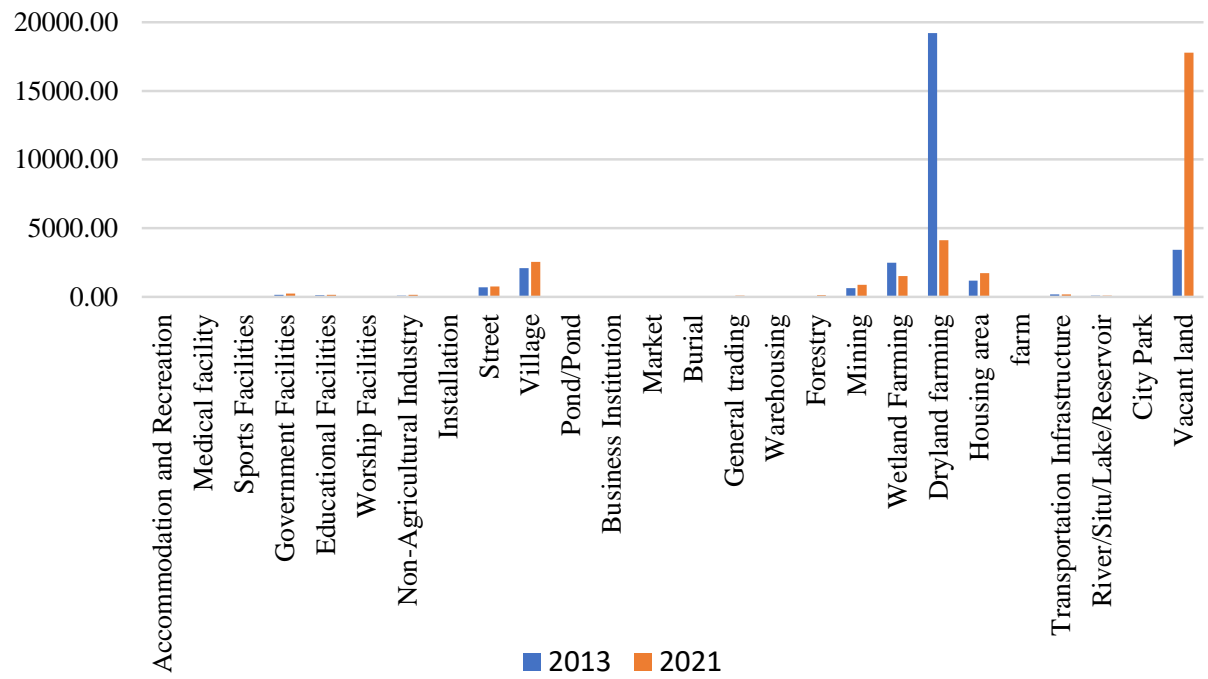

Figure 5. Graph of Overview of Land Use Changes in Banjarbaru City 
From the figure above, it can be seen that the most prominent land use changes are dry land agriculture and vacant land. Land use with the highest change in area over the past eight years is dry land agriculture, then the use of vacant land, wetland agriculture, housing, and villages also experienced major changes. The use of dry land agricultural land has decreased the most in the last eight years, covering an area of $15,090.71$ ha or a decrease of $365.5 \%$ or almost a 4 times decrease. The use of vacant land has increased in an area of 14,372.05 ha or an increase of more than 4 times in the last eight years. Wetland agriculture also experienced a decrease in area, which was reduced by 986.55 ha or decreased by $65.8 \%$ over the last eight years. The decrease in the area of dry land agricultural land and wet land agriculture is due to the fact that both types of land use have changed a lot into vacant land.

The use of land for housing/residential in the form of housing or villages has also undergone considerable changes. Residential land use has increased by 528.10 ha or $44.6 \%$ over the last eight years. The big number of housing needs due to rapid population growth in the City of Banjarbaru is used by developers to build housing. This causes the area of land use for housing to increase significantly. Rapid population growth has also resulted in the addition of villages in the city of Banjarbaru. In the last eight years, the village has increased by 444.32 ha or an increase of $21.2 \%$.

The recapitulation of land use changes that occurred in Banjarbaru City in the period 2013 to 2021 can be seen in the following table:

Table 1 of Land Use Changes in Banjarbaru City Period 2013 - 2021

\begin{tabular}{|c|c|c|c|c|c|}
\hline \multirow{2}{*}{ No. } & \multirow{2}{*}{ Land Use } & \multicolumn{2}{|c|}{ Area (in Ha) } & \multirow{2}{*}{$\begin{array}{l}\text { Land Use } \\
\text { Change }\end{array}$} & \multirow{2}{*}{$\begin{array}{l}\% \\
\text { Changed }\end{array}$} \\
\hline & & Year 2013 & $\begin{array}{l}\text { Year } \\
2021 \\
\end{array}$ & & \\
\hline 1 & Dryland Agriculture & 19219,68 & 4128,97 & $-15090,71$ & $-365,5$ \\
\hline 2 & Vacant Land & 3422,62 & 17794,67 & 14372,05 & 419,9 \\
\hline 3 & Wetland Farming & 2486,57 & 1500,02 & $-986,55$ & $-65,8$ \\
\hline 4 & Housing & 1183,39 & 1711,49 & 528,10 & 44,6 \\
\hline 5 & Villages & 2092,41 & 2536,73 & 444,32 & 21,2 \\
\hline 6 & Mining & 636,55 & 887,22 & 250,67 & 39,4 \\
\hline 7 & Forestry & 20,14 & 119,01 & 98,87 & 490,9 \\
\hline 8 & Government Facilities & 138,73 & 228,18 & 89,44 & 64,5 \\
\hline 9 & Street & 692,28 & 762,48 & 70,21 & 10,1 \\
\hline 10 & Non-Agricultural Industries & 80,92 & 140,24 & 59,31 & 73,3 \\
\hline 11 & General Trading & 22,10 & 80,80 & 58,70 & 265,5 \\
\hline 12 & City Parks & 5,69 & 26,39 & 20,70 & 364,1 \\
\hline 13 & Ponds & 11,42 & 27,13 & 15,71 & 137,6 \\
\hline 14 & Ranch 9.0121 .8712 .86142 .8 & 9,01 & 21,87 & 12,86 & 142,8 \\
\hline 15 & River/Situ/Lake/Reservoir & 80,80 & 91,59 & 10,80 & 13,4 \\
\hline 16 & Worship Facilities & 11,32 & 19,99 & 8,67 & 76,6 \\
\hline 17 & Health Facilities & 4,84 & 12,94 & 8,10 & 167,2 \\
\hline 18 & Market & 8,43 & 16,01 & 7,58 & 89,9 \\
\hline 19 & Cemetery & 38,88 & 45,08 & 6,20 & 15,9 \\
\hline 20 & Education Facilities & 127,31 & 132,45 & 5,14 & 4,0 \\
\hline 21 & Business Institutions & 15,04 & 18,75 & 3,70 & 24,6 \\
\hline 22 & Accommodation and Recreation & 17,69 & 20,99 & 3,29 & 18,6 \\
\hline
\end{tabular}


Setya Etika Mulyasari, Suyanto, Gusti M. Hatta, Bambang Joko Priatmadi

\begin{tabular}{llllll}
\hline 23 & Warehousing & 3,11 & 5,13 & 2,02 & 65,0 \\
\hline 24 & Sports Facilities & 19,99 & 20,65 & 0,66 & 3,3 \\
\hline 25 & Installation & 3,75 & 3,92 & 0,16 & 4,3 \\
\hline 26 & Transportation Infrastructure & 189,85 & 189,85 & 0,00 & 0,0 \\
\hline
\end{tabular}

Source: Results of Land Use Change Analysis for the Period of 2013 - 20121

Note: The negative sign (Minus) represents a decrease in the area of land use

The use of land as roads has increased by 70.21 ha when compared to the data in 2013 or an increase of $10.1 \%$. The rapid development in Banjarbaru City has resulted in an increase in the volume of road infrastructure development. The construction of the office area for the South Kalimantan Provincial Government in Cempaka District and the construction of the Syamsudin Noor International Airport in Landasan Ulin District have led to the construction of many new road accesses in both locations. Land use for markets also increased by 7.58 ha when compared to land use data for markets in 2013. The development of Bauntung Baru market and Pondok Mangga market are two of the new markets that did not exist before.

The use of mining land has also increased in an area of 250.67 ha or an increase of $39.4 \%$ over the last 8 years. Although the mining activities of PT. Galuh Cempaka stopped since 2009-2017, the mining area in Banjarbaru City continues to increase. This shows that there are still traditional diamond mining activities (Panning) by the community in Cempaka District and excavation C mining (Sand, gravel, and backfill) in Landasan Ulin District. The use of forested land has increased significantly compared to 2013 data. The development of the South Kalimantan Provincial Government office area in Cempaka District has an indirect impact on increasing the forest area in Banjarbaru City which is almost five times compared to the data eight years ago. The South Kalimantan Provincial Government built a Miniature Tropical Rain Forest (Miniature Tropical Rain Forest) which is now renamed the Indonesian Tropical Rain Forest Park (TH2TI) in the office area which covers an area of approximately 70 hectares. The development of the Indonesian Tropical Rain Forest Park (TH2TI) is a concrete manifestation of the role of the South Kalimantan Provincial Government in preserving the environment and Indonesian forest resources for future life. The purpose of the development of the Indonesian Tropical Rain Forest Park (TH2TI) is to preserve the diversity of tree species, absorb emissions and create a micro-climate, providing multipurpose forest benefits in the life of society and the nation that ensures the sustainability of sustainable life in the future.

The use of aquatic land (River/Situ/Lake/Reservoir) increased by 10.80 ha or $13.4 \%$ of the 2013 data. One of the reasons for this increase was the construction of the Banua Botanical Garden Embung which was also built in the provincial government office area. South Kalimantan. The purpose of the construction of the reservoir is for flood control conservation and water supply for watering trees/plants in the Banua Botanical Gardens (Wurbs, Cabezas, \& Tibbets, 1985). In addition to these functions, the reservoir will also be used as a tourist spot (Sianturi, Koswara, \& Elysiyah, 2021).

Land use in the form of city parks also experienced an increase in area of $364.1 \%$ or an area of 20.70 ha when compared to data eight years ago which was only 5.69 ha. The Banjarbaru City Government for the past eight years has been very concerned about the development of city parks as a provision of Green Open Space (RTH) in its area, such as the Taman Pintar Green Open Space and the Happy Park Green Open Space. The existence of green open space is very important for an urban area. Aside from being one of the community's social facilities, the city's green open space is expected to be able to 
match the space requirements for community activities with the preservation of the natural landscape of the area. The city's green open space also has many functions and benefits, including hydrological, ecological, climatological, educational, health and tourism functions (Soeriaatmadja \& Wulanningsih, 2018).

Based on the results of spatial analysis, it was found that the land use with the biggest change was dry land agriculture which turned into vacant land, which was $13,653.02$ ha. The use of land for wetland agriculture turned into vacant land covering an area of $950.81 \mathrm{ha}$. This is due to the large number of dry land agricultural lands (moor/fields) and wet land agriculture (paddy fields) that were previously cultivated and cultivated by local farmers/land owners are currently no longer cultivated and become vacant land/shrubs/sleeping land. According to (Wowiling, Sondakh, Katiandagho, \& Ruauw, 2014), the factors that affect agricultural land not being cultivated and becoming idle land are:

a) Physical factors, including soil fertility level, soil capability class, and availability of irrigation networks.

b) Social factors, including the availability and cost of labor, the level of community education, and the ability of individuals in agricultural cultivation.

c) Economic factors, including capital, the cost of agricultural equipment and technology is relatively expensive, the level of community income from the nonagricultural sector.

Detailed reasons that cause farmers in Banjarbaru City to no longer cultivate their land for agricultural activities need more in-depth study and research. In addition to turning into vacant land, dry land agricultural land is also transformed into vacant land turned into other land uses such as educational facilities, health facilities, sports facilities, roads, public trade, housing, villages and others (Li, Wang, Wuzhati, \& Wen, 2016). Similar to dry land agriculture, wetland agriculture also changes towards non-agricultural activities, such as educational facilities, health facilities, sports facilities, roads, public trade, housing, villages and others (Thuo, 2013).

One of the sports facilities was also transformed into a market covering an area of 3.80 ha, namely a mini stadium on Jalan RO Ulin which turned into Bauntung Baru Market. The use of village land has turned into general trading covering an area of 14.68 ha in the last eight years.

Broadly speaking, the types of land use in Banjarbaru City in 2021 will shift with the types of land use in 2013, both types of land use, area, and distribution. The use of dry land agricultural land and wetland agriculture has decreased in area in the last eight years. This illustrates that there has been a shift in the activities of the people of Banjarbaru City in utilizing their land from agricultural activities to non-agricultural activities, as well as a change in the mindset/paradigm of the younger generation who no longer want to be involved in agricultural activities and no longer want to work their land for dry land agricultural activities moor/fields) and wetland agriculture (paddy fields) (Lee-Martinez, 2014).

Based on the spatial analysis with the land use type approach, it can be concluded that the land use changes that occurred in Banjarbaru City in the period 2013-2021 were mostly carried out by the community, covering an area of $15,546.80$ ha or $94.7 \%$ of the changes that occurred in that period, namely in the form of villages, vacant land, dry land agriculture, ponds, worship facilities, and others. An area of 540.62 ha or $3.3 \%$ of the changes that occurred during that period were carried out by legal entities (Private). Changes in land use, the subject of which is a legal/private entity, occur in the use of residential land, business institutions, warehousing, and recreation and accommodation such as the Grand Daffam hotel and Q Mall Banjarbaru. The remaining area of 326.58 ha 
or $2 \%$ of the changes that occurred during that period was carried out by the Government. Changes in land use, the subject of which is the government, occurs in the land use of government facilities, sports facilities, markets, forestry, roads, installations, and others.

\section{B. Sustainability of Land Use to the RTRW of Banjarbaru City}

According to (Rustiadi, 2018), in the spatial planning paradigm it is defined as a form of systematic assessment of the physical, social and economic aspects to support and direct the use of space in choosing the best way to increase productivity in order to meet the needs of the community (Public) in a sustainable manner. The process of spatial planning is basically an effort to create various balances (Nutters \& da Silva, 2012). The spatial planning process requires a participatory balance between various parties that leads to the establishment of justice between parties.

The difference between the current condition and the spatial utilization plan can cause various problems in the implementation of the space utilization plan. The problem lies in the use of space that is not in accordance with the spatial plan, especially in urban areas where the physical development of buildings continues to increase. Therefore, it is necessary to make efforts to adjust land use to the Regional Spatial Plan, the need for an analysis of the suitability of land use to the Regional Spatial Plan (RTRW), considering that there are many changes in land use patterns, both those that are in accordance with the plan or the allocation of land use in spatial planning and unplanned.

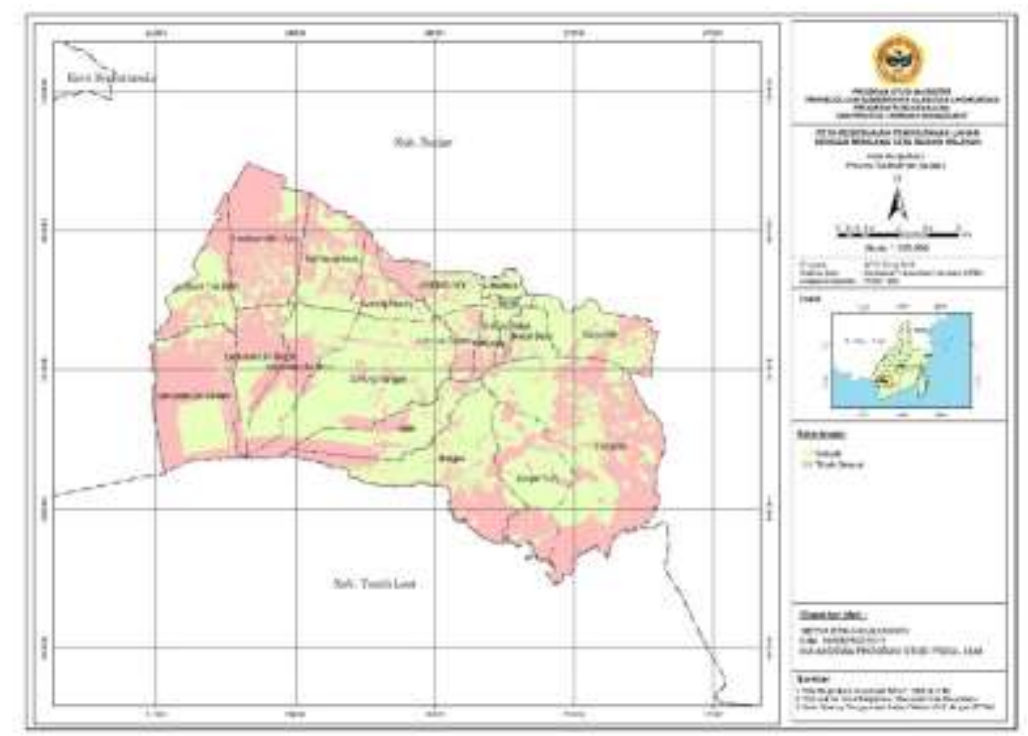

Figure 6 Map of the suitability of land use for the RTRW

Banjarbaru City Spatial Planning is regulated in Banjarbaru City Regional Regulation Number 13 of 2014 concerning Banjarbaru City Spatial Planning. The Regional Regulation is used as a direction in the regional development process. As a guiding instrument, every space use should procedurally apply for a space use permit to the authorized agency. 


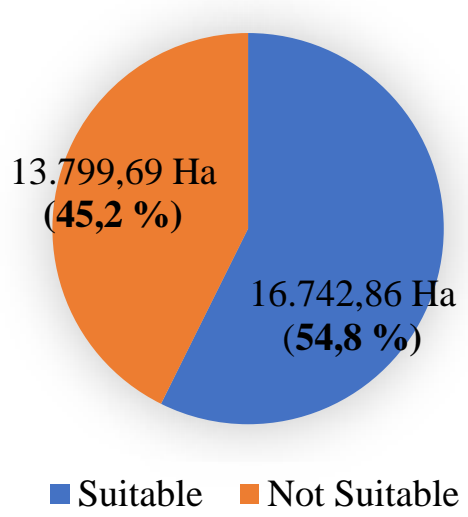

Figure 7 Graph of Land Use Suitability to RTRW

Although the use of space has been regulated through the Regional Spatial Plan (RTRW), there are still spatial uses that are not in accordance with the direction of the RTRW (Hajer \& Zonneveld, 2000). Based on the analysis of spatial data based on the suitability matrix, it can be seen that an area of $16,742.86$ ha or $54.8 \%$ of land use in Banjarbaru City is categorized according to the Regional Spatial Plan, while an area of $13,799.69$ ha or another $45.2 \%$ land use. categorized not in accordance with the direction of the function of space in the Regional Spatial Plan.

\section{CONCLUSION}

Based on the results of the research described in the previous chapter, the following conclusions can be drawn: 1) There was a change in land use in Banjarbaru City in the period 2013-2021. In an area of 16,414.00 ha (53.7\%) there was a change in land use, while an area of 14,128.54 ha (46.3\%) did not change in land use (No change). 2) The biggest land use changes over the last eight years are dry land agriculture, vacant land, wetland agriculture, housing and villages. The use of dry land agricultural land experienced the largest decrease in area of $15,090.71$ ha or a decrease of $365.5 \%$ or almost a 4-fold decrease. The use of vacant land increased in an area of 14,715.684 hectares or an increase of almost 4 times. Wetland agriculture has decreased in area which is reduced by 986.55 ha or decreased by $65.8 \%$. The use of land for housing/residential in the form of housing or villages has also undergone considerable changes. Residential land use increased by 528.105 hectares (44.626\%) and the village area to 444.32 ha (21.2\%). 3). The suitability of land use with the RTRW in Banjarbaru City is 16,742.86 ha (54.8\%) categorized as appropriate, while an area of 13,779.69 ha $(45.2 \%)$ is categorized as not in accordance with the applicable RTRW.

\section{REFERENCES}

Arsyad, Sintanala. (2006). Konservasi Tanah dan Air. Institut Pertanian Bogor. IPB Press. Hlm.

Bruinsma, Jelle. (2009). The resource outlook to 2050: by how much do land, water and crop yields need to increase by 2050. Expert Meeting on How to Feed the World In, 2050, 24-26. 
Hajer, Maarten, \& Zonneveld, Wil. (2000). Spatial planning in the network societyrethinking the principles of planning in the Netherlands. European Planning Studies, 8(3), 337-355.

Lambin, Eric FMDA, Rounsevell, Mark D. A., \& Geist, Helmut J. (2000). Are agricultural land-use models able to predict changes in land-use intensity? Agriculture, Ecosystems \& Environment, 82(1-3), 321-331.

Lee-Martinez, Amorina. (2014). Restoring the Colorado River Delta: Finding common ground for our water.

Li, Jie, Wang, Fang, Wuzhati, Shuake, \& Wen, Bufan. (2016). Urban or village residents? A case study of the spontaneous space transformation of the forced upstairs farmers' community in Beijing. Habitat International, 56, 136-146.

Maclean, Kirsten, Robinson, Catherine J., \& Natcher, David C. (2015). Consensus building or constructive conflict? Aboriginal discursive strategies to enhance participation in natural resource management in Australia and Canada. Society \& Natural Resources, 28(2), 197-211.

Nutters, Heidi M., \& da Silva, Patricia Pinto. (2012). Fishery stakeholder engagement and marine spatial planning: Lessons from the Rhode Island Ocean SAMP and the Massachusetts Ocean Management Plan. Ocean \& Coastal Management, 67, 9-18.

Rustiadi, Ernan. (2018). Perencanaan dan pengembangan wilayah. Yayasan Pustaka Obor Indonesia.

Sianturi, R. S., Koswara, A. Y., \& Elysiyah, I. (2021). Recommending assembly points, evacuation routes, and standard operating procedures for potential flooding due to reservoir dam failures: a case study of Gondang Reservoir, Lamongan, East Java. IOP Conference Series: Earth and Environmental Science, 778(1), 12004. IOP Publishing.

Sivakumar, Mannava V. K. (2005). Impacts of natural disasters in agriculture, rangeland and forestry: an overview. Natural Disasters and Extreme Events in Agriculture, 122.

Soeriaatmadja, A. R., \& Wulanningsih, R. (2018). A set of sustainable urban landscape indicators and parameters to evaluate urban green open space in Bandung City. IOP Conference Series: Earth and Environmental Science, 179(1), 12016. IOP Publishing.

Thuo, Aggrey Daniel Maina. (2013). Impacts of urbanization on land use planning, livelihood and environment in the nairobi rural-urban fringe, Kenya.

Wowiling, Rizki E., Sondakh, Mex F. L., Katiandagho, Theodora M., \& Ruauw, Eyverson. (2014). Analisis Sosial Ekonomi Masyarakat Terhadap Bertambahnya Lahan Tidur di Desa Taraitak Kecamatan Langowan Utara. COCOS, 5(3).

Wurbs, Ralph A., Cabezas, L. Morris, \& Tibbets, Michael N. (1985). Optimum reservoir operation for flood control and conservation purposes. Texas Water Resources Institute.

Wuryanta, Agus, Susanti, Pranatasari Dyah, Yani, Jl A., \& Pabelan, P. O. (2015). Analisis Spasial Tekanan Penduduk Terhadap Lahan Pertanian DI Sub DAS Keduang, Kabupaten Wonogiri, Jawa Tengah. Forestry Research, Development and Innovation Agency.

Yaping, Wei, \& Min, Zhao. (2009). Urban spill over vs. local urban sprawl: Entangling land-use regulations in the urban growth of China's megacities. Land Use Policy, 26(4), 1031-1045. 